\title{
Polyethylene Glycol Hydrogel
}

National Cancer Institute

\section{Source}

National Cancer Institute. Polyethylene Glycol Hydrogel. NCI Thesaurus. Code C118668.

A 2- or 3-dimensional hydrophilic, cross-linked polymer of polyethylene glycol (PEG). These hydrogels can be used as scaffolds for tissue engineering or as drug delivery carriers. 